\title{
Editorial
}

\section{Challenges for deposit insurers in resolving bank failures}

Journal of Banking Regulation (2006) 8, 1-3. doi:10.1057/palgrave.jbr.2350039

This special edition of the Journal of Banking Regulation is comprised of papers, which were presented at the Fourth Annual Conference of the International Association of Deposit Insurers (IADI) in Taipei, Taiwan from the 27th to 29th September, 2005. The subject chosen for the Conference was 'Challenges for Deposit Insurers in Resolving Bank Failures'.

IADI's mission is to contribute to the effectiveness of depositor protection arrangements by developing guidance and promoting international cooperation. Its vision of sharing deposit insurance expertise is fulfilled through its annual conferences and other such events, which are also used as a means to highlight the work of the Association in developing guidance. The Fourth Annual IADI Conference was an opportunity for IADI to present two new Guidance papers related to the resolution of bank failures and to expose important work that has been going on in related areas.

It is fitting for a Journal such as this, which aims to be both scholarly and practical, to have the opportunity to publish papers presented on a topic which is of considerable and contemporary importance to all of those involved whether as bankers, bank regulators, central bankers, politicians, economists, financial sector lawyers or as officers of a deposit insurance agency. The papers cover a wide range of important issues, all of which are relevant to the question of the protection of bank depositors, and they are written by leading international experts from a variety of jurisdictions and different professional backgrounds.

Readers of the Journal will already be aware of the important role which banks play in the modern world, both from an economic and social perspective, and the role that banks play in transforming risks. Financial crises in which banks have failed have been an all too common phenomenon throughout the world in recent years. In the latter part of the previous century, a number of countries experienced very serious systemic crises that caused governments to implement blanket guarantees, while others may only have had to deal with the occasional problem bank.

One of the constituent parts of a financial safety net is the provision of some degree of protection to those individuals who place their savings in banks. This may range from simply giving depositors legal priority on bankruptcy to the provision of some degree of compensation using a deposit insurance system. The idea of providing explicit limited protection to bank depositors often proves to be surprisingly controversial and any discussion of the subject tends to produce a wide range of views, both for and against. Some commentators are totally opposed in principle, as they believe that the problems created by an increase in moral hazard (and other factors) are greater than the benefits gained by providing explicit protection to depositors. Among those who support the concept there remains a wide range of issues, which require further consideration.

It is well known that effective deposit insurance arrangements preserve the benefits of heightened financial stability and small depositors' protection without at the same time increasing moral hazard or reducing market discipline. Among those who support this concept there remains a wide range of 
issues, which require further consideration. These include matters such as:

- How much protection should be provided?

- What types of deposits should be protected?

- How should the system be funded?

- Should the deposit insurance organisation merely act as a pay-box or should it have a wider role in promoting financial stability?

- What is the role of the deposit insurer in the resolution of bank failures?

It is the last of these, which is the focus of the papers in this volume. The six papers presented in this edition of the Journal discuss a wide range of issues, all of which are crucial to the contemporary debate and which will stimulate further discussion in relation to the role of deposit insurance in the resolution of banking failures.

A key responsibility for a depositor protection organisation is to be in a position, as soon as it begins operating, to reimburse depositors when a bank fails. A basic requirement is for the deposit insurer to know when a bank failure is going to happen. But not all deposit protection agencies know when that is going to happen, given the nature of their mandates, roles and responsibilities. The purpose of the paper by John Raymond LaBrosse and David $\mathrm{K}$. Walker is to set out some practical considerations regarding the advance planning that deposit protection agencies should consider doing in order to fulfil their mandates particularly with respect to reimbursing depositor claims in a timely fashion after a bank failure.

Winston Carr gives consideration to the need for coordination of efforts between all of the safety net participants and he states that 'the aim of this paper is to provide practical advice to safety net participants on how to promote interrelationships that will contribute to financial stability'. David Mayes examines two possible solutions to the problem of foreign-owned systemic bank branches, and in doing so he contrasts the position in the Nordic-Baltic countries with that of Australia and New Zealand. His paper very much highlights the nature of the problems that exist when banks start operating on a cross-border basis. In highlighting the fact that small countries generally find that the banks become foreign-owned, he draws our attention to a development that many may not have been aware of until now. The potential problems for deposit insurers are highlighted.

Gulen Atay provides a lawyer's perspective and she is very well qualified to do this as a principal counsel at the Asian Development Bank. She is of the opinion that there is a need for international cooperation in the resolution of bank failures and notes that, at present, banking regulation tends to be nationally based and this can lead to a legal framework which theories considerably from jurisdiction to jurisdiction. Attention is drawn to the work being done by international and regional organisations in promoting international cooperation in this area.

The objective of the paper by William Su on behalf of the IADI's Sub-committee on Developing Guidance for the Resolution of Bank Failures 'is to develop general guidance for deposit insurers and other safety net participants interested in establishing or enhancing their mechanisms for the resolution of failed or failing banks, and is designed to take into account different country circumstances, settings and structures'.

George Kauffman recognises that 'deposit insurance in some form or other is a political reality in effectively all countries that have a banking system'. He is of the opinion that deposit insurance is not without its problems and moral hazard and poor agency behaviour are highlighted. While not everyone will be in agreement about this, he presents a very thought-provoking and well-argued paper in which an interesting solution to the perceived problems is presented.

There are likely to be many developments in relation to the resolution of banking crises in the coming years and, at the same 
time, much will, hopefully, continue to be done in an attempt to provide a more stable environment internationally in which banks can operate. As new countries continue to introduce deposit insurance systems, and those with existing ones consider improvements, the role of the deposit insurer in the resolution of bank failure will continue to develop and this will be something that should be monitored closely.

The debate on the role of deposit insurance in the modern financial infrastructure will undoubtedly continue and will hopefully reach a wider audience in the future. It is hoped that readers find this special edition of the Journal of
Banking Regulation to be an important contribution to the debate.

\section{Guest Editors}

Andrew Campbell ${ }^{1}$ and John Raymond LaBrosse ${ }^{2}$

${ }^{1}$ Director of the Centre for Business Law and Practice, University of Leeds, Leeds, UK

${ }^{2}$ Secretary General, International Association of Deposit Insurers, C/o Bank for International Settlements, Basel, Switzerland e-mail: Ray.LaBrosse@iadi.org 